This item was submitted to Loughborough's Research Repository by the author.

Items in Figshare are protected by copyright, with all rights reserved, unless otherwise indicated.

\title{
Individual entrepreneurial orientation and intrapreneurship in the public
} sector

PLEASE CITE THE PUBLISHED VERSION

https://doi.org/10.1007/s11365-019-00593-6

PUBLISHER

Springer

VERSION

AM (Accepted Manuscript)

\section{PUBLISHER STATEMENT}

This is a post-peer-review, pre-copyedit version of an article published in International Entrepreneurship and Management Journal. The final authenticated version is available online at: https://doi.org/10.1007/s11365019-00593-6

\section{LICENCE}

CC BY-NC-ND 4.0

\section{REPOSITORY RECORD}

Kraus, Sascha, Matthias Breier, Paul Jones, and Mathew Hughes. 2019. "Individual Entrepreneurial Orientation and Intrapreneurship in the Public Sector”. figshare. https://hdl.handle.net/2134/38164. 


\section{Individual Entrepreneurial Orientation and Intrapreneurship in the Public Sector}

Sascha Kraus, École Supérieure du Commerce Extérieur, ESCE International Business School, 10 rue Sextius Michel, 75015 Paris, France; sascha.kraus@esce.fr

Matthias Breier, Lappeenranta University of Technology, School of Business, Skinnarilankatu 34, 53850 Lappeenranta, Finland; matthias.breier@gmx.at

Paul Jones, Swansea University, School of Management, Bay Campus, Swansea SA1 8EN, United Kingdom; w.p.jones@swansea.ac.uk

Mathew Hughes, Loughborough University, School of Business and Economics, Loughborough LE11 3TU, United Kingdom; m.hughes2@lboro.ac.uk 


\title{
Individual Entrepreneurial Orientation and Intrapreneurship in the Public Sector
}

\begin{abstract}
This paper investigates the relationship of individual entrepreneurial orientation (IEO) and intrapreneurial activities in the public sector. Moreover, the influence of the two self-regulatory modes locomotion and assessment are used to provide further insights into this relationship. This empirical study focuses on a quantitative analysis of 266 public sector employees from municipalities and cities in the Germanspeaking countries gathered through an online survey. The results demonstrate that public sector employees with a high level of IEO are more likely to work on explorative activities which are the foundation for every intrapreneurial process. Furthermore, the results highlight that IEO does not have an influence on exploitative activities. The respective self-regulatory mode is identified as an important moderator for the relationship. Our research shows that an archetype of an intrapreneur who is strong in scanning for new opportunities and evaluating them is possible.
\end{abstract}

\section{Keywords}

Intrapreneurship, Individual Entrepreneurial Orientation, Public Sector

\section{Introduction}

Intrapreneurship, Corporate Entrepreneurship (CE), Corporate Venturing or Intrapreneuring are all (widely synonymously used) terms that deal with the creation of something new out of an existing organization (Burgelman, 1983; 1985; Lumpkin and Dess, 1996; Pinchot, 1985). This renewal and revitalization of an organization leads to positive consequences on organizational performance (Schollhammer, 1981, 1982; Kanter, 1984; Rule \& Irvin, 1988; McKinney \& McKinney, 1989; Guth \& Ginsberg, 1990; Zahra, 1991). The effects of intrapreneurship are typically investigated in private companies. However, also municipalities now face a growing series of challenges and resource constraints that fundamentally call into question their historical activities and ways of doing things. In turn, the challenges of municipalities justifies investigating intrapreneurship in municipalities and cities as well.

The entrepreneurial orientation (EO) of employees is attracting growing research interest in recent years. Bolton \& Lane (2012) developed a scale to analyze the individual entrepreneurial orientation (IEO) of employees. The origin of IEO is based on EO itself (Mustafa et al., 2018). Specifically, the original Covin and Slevin EO scales focus on individuals in the guise of organizations' most senior managers - its CEOs - but do not specifically regard them as individuals, but rather only as representatives who speak for the whole company. This position relies on the efficacy of upper echelon theory to 
explain why organizations in time come to reflect their senior managers (Covin \& Miller, 2014; Hambrick and Mason, 1984). Hence, CEO EO becomes organizational EO. The hegemony of this position is problematic. First, it has led to a denial of the possibility that EO might exist at other levels of analysis within the organization (Covin and Wales, 2019). Second, the theory fails to explain adoption of EO characteristics and exhibition of EO behaviors elsewhere in the organization (e.g., Wales et al., 2011). In turn, only the EO of organizations constituted by EO levels of key Decision-makers (mainly CEOs) are regularly investigated. Third, and in contrast, it is not only the CEO himself who fosters innovation. Employees are an important factor to creating innovation within a firm (Hughes et al., 2018). For example, when effectively galvanized, employees try to solve organizational issues (Zampetakis \& Moustakis, 2010, 2012), innovate in the workplace to enhance workplace performance (Hughes et al., 2018), facilitate intrapreneuring behavior (Mustafa et al., 2016), and create new ideas to fight competition (Croonen et al., 2016).

The aim of this article is to examine the relationship of an individual orientation of an employee and his ability to conduct intrapreneurship in municipalities and cities. Therefore, we investigate the relationship of IEO with exploration and exploitation as two phases of CE (exploration, the opportunity identification phase, and the phase of exploiting the newly found opportunity within the organization) on the basis of 266 respondents in the context of municipalities and cities of every size. While exploration activities are the foundation for intrapreneurial success, exploitation activities are necessary to keep the organization running.

\section{Theoretical foundations and development of hypotheses}

The most open definition used for intrapreneurship is "entrepreneurship within existing firms" (Antoncic \& Hisrich, 2001, p. 497). It means the creation of something "new" (Lumpkin and Dess, 1996), and describes a process of innovating and implementing regardless of the resources currently controlled (Carrier, 1996; Stevenson \& Jarillo, 1990). Therefore, CE is a two-phased approach. The first phase within an intrapreneurial process is opportunity recognition. The second phase is the implementation of the intrapreneurial idea and the exploitation of the opportunity (Heinze \& Weber, 2016; Sarasvathy, 2001; Eckhardt \& Shane, 2003). Both phases are essential for a successful intrapreneurial process (Heinze \& Weber, 2016).

\section{A new logic: Exploring a new opportunity}

Existing firms are an imperfect environment for the construction of new business (Fast \& Pratt, 1981). However, these organizations are a procreative ground for opportunities, as they already provide potential funding, which is an effective combination to start innovations (Burgelman, 1983). Opportunities in 
intrapreneurship arise from changes in institutions and the surrounding environment (Sine \& David, 2003). While entrepreneurship concentrates on the recognition and exploitation of opportunities (Eckhardt \& Shane, 2003), intrapreneurship is stronger tied to the creation of these opportunities. Opportunities must be searched proactively, while the incumbent organization and their employees are typically not interested in change; this is in part because salaried employees do not require to or necessarily have a risk-taking appetite in the role they occupy (e.g., Hughes and Mustafa, 2017), unless they bear a form of entrepreneurial orientation intrinsically. Based on the research of Heinze and Weber (2016), the relationship between creation and exploitation is described as closer in intrapreneurship than in entrepreneurship. The authors demonstrated that one employee can create the opportunity and exploit it simultaneously in an intrapreneurial process. Eckhardt \& Shane (2003) also show that an employee with a positive cognition of entrepreneurship will result in a higher opportunity recognition. For employees searching for new opportunities, a strong explorational approach is expected to be important.

\section{Implementation: Exploiting the opportunity}

Heinze and Weber (2016) investigated the implementation process of an intrapreneurial process and derived five intrapreneurial tactics to implement an opportunity. New logics are initially isolated because of their limited dissemination new ideas are easily ignored within the organization (Weber et al., 2008). This results in the necessity of conflicts between the upcoming and existing logic (Zietsma \& Lawrence, 2010). That conflict can result in different possible outcomes ranging from a total integration of the new logic to a symbolic adoption or its rejection (Westpahl \& Zajac, 2001; Kraatz \& Block, 2008). In this implementation process, the intrapreneur (the person integrating the new idea) is a key person (Briscoe \& Safford, 2008). However, not everyone within the organization may support or share the same belief in the emerging new logic. There are always individuals that are afraid of losing out when a new logic emerges and resist it, resulting in "passionate resistance" (Heinze \& Weber, 2016, p. 157; Haveman \& Rao, 1997).

Institutional change can foster new opportunities. It can be described as an effect coming in waves and existing in times of no change and times of change. Internal workers in an improved position to change organizations and integrate a new logic because they are part of the organization, enjoy trust and may take part in the decision-making process (Heinze \& Weber, 2016). Nevertheless, they further describe intrapreneurship as a strategy of lower and mid-level employees, and these employees do not typically possess sufficient decision-making power. Advantageously, however, a lower status in their organization means such individuals are likely to become dissatisfied with existing systems, resulting in their drive for intrapreneurship (Battilana, 2006; Howard-Grenville, 2007; Meyerson \& Scully, 1995).

\section{The inner dimension of intrapreneurship}


Antoncic and Hisrich (2001) developed a four-dimensional model for intrapreneurship. First, the dimension of new business venturing can be constituted in two different possibilities. Opportunities can be exploited within the firm (Stopford \& Baden-Fuller, 1994) in the form of new products or services (Rule \& Irwin, 1988). Another possibility is the creation of a spin-off, a new firm with a less formal relationship than the original (Zahra, 1991; Anton \& Yao, 1995). Based on the form of formalization and the distance between the existing and the new venture, scholars use different expressions such as internal venturing, autonomous business unit creation, corporate start-ups or newstreams to represent new business venturing (Vesper, 1984; Hisrich \& Peters, 1984; MacMillan et al., 1984; Kanter \& Richardson, 1991).

Second, the innovation dimension includes the creation of new products, services or methods of production (Schollhammer, 1982). Therefore, intrapreneurship makes use of incremental and radical innovation (Schumpeter, 1942, Antoncic \& Hisrich, 2001), which is the advancement of products and services as well as technologies (Knight, 1997). However, some research constituted intrapreneurship as mainly incremental development, as intrapreneurs are less influential in the organization than the influence typically granted to or available to an entrepreneur (Heinze \& Weber, 2016).

Third, self-renewal addresses the transformation of organizations in a highly embattled environment. Organizations today are influenced by pressure from the four sides of customer, competitor, technology and legal changes (Kuratko et al., 2011). Based on today's transient environment, organizations must rethink their business model, whether they are private or public entities. The revitalizing effect of intrapreneurship motivates employees, creates new strategies and leads to improved financial figures (Zahra, 1991). Zahra (1993) demonstrated in a study that the dimension fosters several important factors like the strategic orientation, the organizational change and a refinement of the business concept. Furthermore, a strategic change of the business is viewed as a form of intrapreneurship (Vesper, 1984). Further supporting that an entrepreneurial corporation as one that can stay flexible, adaptable and able to renew the business (Muzyka et al., 1995).

Fourth, proactiveness is a dimension deeply established in the entrepreneurship literature. Proactiveness is an aggressive strategy to compete with competitors (Knight, 1997), constituted by taking risks and following an experimental approach (Stopford \& Baden-Fuller, 1994). A proactive orientation constitutes a strong leader role for a business in taking the initiative to find and exploit opportunities. By trying to creating new opportunities rather than checking or mirroring the competitor, they perform an aggressive strategy to compete with rivals (Lumpkin \& Dess, 1996; Covin \& Slevin, 1991).

\section{Development of Hypotheses}

\section{Individual Entrepreneurial Orientation in the Context of Exploration and Exploitation}


The relationship between firm performance and EO is an often-investigated research question. Authors claim EO to be a unidimensional construct and explain the different dimensions (risk-taking, innovativeness and proactiveness) to have similar effects on performance (Covin \& Slevin, 1989). However, newer supports other results too (see Covin \& Wales, 2019). Authors describe that the dimensions can occur in different combinations and that the effect of the sub-dimensions could vary (Lumpkin \& Dess, 2001; Covin et al., 2006; Hughes \& Morgan, 2007; Kraus et al., 2018).

Earlier, we demonstrated the importance of investigating IEO in the form of individual entrepreneurial behavior (Mustafa et al., 2018). Our position is that for organizations to effectively harness and realize the potential of senior manager's EO for the firm, employees must express behaviors that are akin to firm EO in the form of IEO. Indeed, recent (re)conceptualizations of EO suggest that it bears an attitudinal and behavioral element (Anderson et al., 2015). While underdeveloped, it is likely that to employees, the expression by senior managers of firm EO is emblematic of organizational attitude, the desire of senior managers. But unless employees themselves exhibit intrapreneurial behavior, the potential of firm EO may go unrealized. The efforts of employees (Hughes et al., 2018) and the extent of their ownership of intrapreneurship (Mustafa et al., 2016) is theoretically vital. This investigation outlines the influence of IEO as an overall concept on work activities and shows the relationship of the sub-dimensions risk-taking, innovativeness and proactiveness on the two possible intrapreneurship activities of exploration and exploitation.

Several studies have already investigated the EO of an organization and have highlighted the relationship to performance. However, not all studies found a positive one (Rauch et al., 2009). Moving to an individual level, Hughes et al. (2018) recently identified that innovative behavior influences individual and team workplace performance positively. Individuals engaging in explorative activities are considered to be potentially successful intrapreneurs. Being explorative is described as investing time into new activities, which is similar to the self-renewal dimension which Antoncic and Hisrich (2001) described intrapreneurship to be based on. Therefore, working (intra)entrepreneurially in a new unknown environment is explorative. By contrast, exploitational work deals with routines, refinement and execution.

Risk-taking as being part of an entrepreneurial (and therefore also intrapreneurial) process is founded in the early definitions of Cantillon (1734). An entrepreneur faces several risks, from financial ones to reputational; however, also employed staff face forms of personal risks within their roles. Especially by working on explorative activities, employees must sometimes cross the border of the organization's strategy and culture (Shane, 1994; Day, 1994). An employee working on explorational activities faces a high personal risk. Within an organization, the risk dimension is more personal. It includes to challenge existing norms (Heinonen \& Toivonen, 2008) or reduce bureaucracy (Zampetakis \& Moustakis, 2007; 2010). Often, they may not be supported by management (Mustafa et al., 2018), re- 
sulting in further personal risk for the employee. These risky behaviors are more likely to support explorative behavior than exploitative. For exploitative behavior, the tasks are clear and do not allow challenging norms or changing processes to reduce bureaucracy, nor is it strictly necessary. For exploration, such actions are required, exposing the individual employee to risk. Validating this theoretical concern, studies report that trust in ones work colleagues and line managers bear effects on the efficacy of individual innovative behavior, for example (Hughes et al., 2018).

The definition of innovativeness describes explorative activities dealing with something new and unknown (Schumpeter, 1942; Lumpkin \& Dess, 1996). Although innovation varies between its level of newness (Hage, 1980), it typically deals with the will to update something old to a newer version, identifying opportunities, generating new ideas and developing new products/services (Subramaniam \& Youdt, 2005), even at a cost to established products, services and markets served by the organization (Kyriakopoulos et al., 2016). Atuahene-Gima (2005) described a relationship of exploitation and incremental innovation as well as exploration and radical innovation. The literature review of Mustafa et al. (2018) indicated Innovation as the most common part for personal entrepreneurial behavior.

Proactiveness is an essential part of the entrepreneurial process (Schumpeter, 1942), and, in likelihood, the intrapreneurial process. Proactiveness leads to an earlier detection of new possibilities and opportunities. A problem associated with proactiveness is the implicit time element-whether proactiveness requires some aspect of pre-detection (Covin \& Wales, 2019). However, we see this as a conceptualization of proactiveness as a property, not as a behavior. Proactive behavior refers to efforts by the individual to scan their environment for weak signals and peripheral information in an effort to detect new trends or emerging situations before they fully evolve or take shape. Therefore, it is likely of value to explorational activities. Indeed, Miller and Friesen describe proactive organizations as ones that act early and do not only react on established trends (1978). Extrapolated to the employee, such behavior results in proactive employees working ahead of trends and not only following them. To do so, they must go beyond existing boundaries and leverage their knowledge to seek new solutions.

On these foundations, we establish the following hypotheses:

H1: The higher the IEO characteristics of an employee, the higher the value of exploration.

H1.1: The higher IEO Risk characteristics are, the higher the value of exploration.

H1.2: The higher IEO Innovation characteristics are, the higher the value of exploration.

H1.3: The higher IEO Proactiveness characteristics are, the higher the value of exploration.

H2: The higher the IEO characteristics of an employee, the lower the value of exploitation. 
H2.1: The higher IEO Risk characteristics are, the lower the value of exploitation.

H2.2: The higher IEO Innovation characteristics are, the lower the value of exploitation.

H2.3: The higher IEO Proactiveness characteristics are, the lower the value exploitation.

\section{The influence of locomotion and assessment}

Locomotion and assessment are the two different orientations a person can follow in regulatory mode theory. They are modes of self-regulation and describe how people act (Higgins \& Kruglanski, 2003; Kruglanski et al., 2000). Both modes are tied to entrepreneurship. Locomotion is defined as the movement from one state to another without any direction or destination in mind, whereas, assessment is an "orientation to measure, interpret, or evaluate the rate, amount, size, value or importance of something, to appraise critically for the purpose of understanding or interpreting, or as a guide in taking action" (Avent \& Higgins, 2003, p. 526). The variables shape a person's character and are stable in general, however in specific situations one type can dominate the other (Higgins et al., 2003). Both dimensions are relatively independent of each other, resulting in the possibility of individuals being strong on both locomotion and assessment (Avnet \& Higgins, 2003; Amato et al., 2017). Amato et al. (2017) state that both regulatory modes can be related to opportunity recognition and evaluation. They demonstrated several overlaps of entrepreneurship and self-regulatory modes. Their research shows a highly significant effect of locomotion on the scanning for opportunities, and a highly significant effect of assessment on the evaluation of opportunities. So, locomotion drives people into new opportunities, assessment helps to identify the best alternatives.

Locomotion is an action-based factor that describes people willing to implement new opportunities (Kuhl, 1983 \& 1985). This orientation is an important factor for an intrapreneur when facing an existing organization. Locomotion describes the movement in general, moving from one station to the next (Higgins, 2003). This moving behavior demonstrates a connection with IEO and explorational activities. Action orientation and performance orientation are both factors that are supported and fostered through a locomotion (Sellin et al., 2003). Moreover, locomotion-oriented people are motivated to move from task to task. As a result, they are not interested in doing the same task all the time (Avnet \& Higgins, 2003; Higgins et al., 2003). Considering this prior research, employees with a high value of locomotion are less committed to exploitational activities because these activities are routines that do not allow one to move on. By contrast, they are highly interested in explorative activities where new activities can be repeated daily. Furthermore, locomotion is positively influencing the scanning for new opportunities which shows similarity to EO in case of opportunity recognition. Thus, these are important factors for municipality employees to discover ideas or be open for ideas of private companies.

On this foundation, we assert the following hypotheses: 
H3.1: Locomotion positively influences the relationship of IEO and exploration activities.

H3.2: Locomotion negatively influences the relationship of IEO and exploitation activities.

Assessment is a more strategic orientation compared to locomotion and leads people to consider their behavior more. People with a high manifestation of assessment are likely to deal with the past and not start performing (Furtner \& Sachse, 2017) without evaluating all potential combination and outcomes (Amato et al., 2017). Employees who have a high level of assessment analyze possibilities and wait for alternatives before they decide (Sok et al., 2016). They work "to do the right thing" (Kruglanski et al., 2000, p. 793). Assessment oriented employees are more effective in finding inefficiencies and in correcting them. It is positively influencing association and evaluation, which eventually leads to business success (Amato et al., 2017). Here the authors expect assessment to moderate the relationship of IEO and exploration and exploitation. Employees with a strong expression of assessment are expected to be able to implement strategies because of their willingness to focus intently on their work, and do so with stamina and persistence. We thus hypothesize:

H4.1: Assessment negatively influences the relationship of IEO and exploration activities.

H4.2: Assessment positively influences the relationship of IEO and exploitation activities.

\section{Empirical Part}

\section{Methodology}

This study is based on a quantitative methodology to understand the underlying research model (see figure 1) and test the hypotheses. The data for the empirical analysis was collected through an online survey, which was conducted in April 2018 and which addressed the employees of municipalities and cities in the German-speaking regions of Europe, i.e. Austria, Germany, Liechtenstein and Switzerland. We sent the questionnaire to 1,694 randomly-selected municipalities and collected a total of 266 individual responses after deleting incomplete surveys. This results in a response rate of $15.7 \%$, which is above average for an academic survey of this type in the German-speaking named countries (e.g., Kraus et al., 2018; Eggers et al., 2019). 


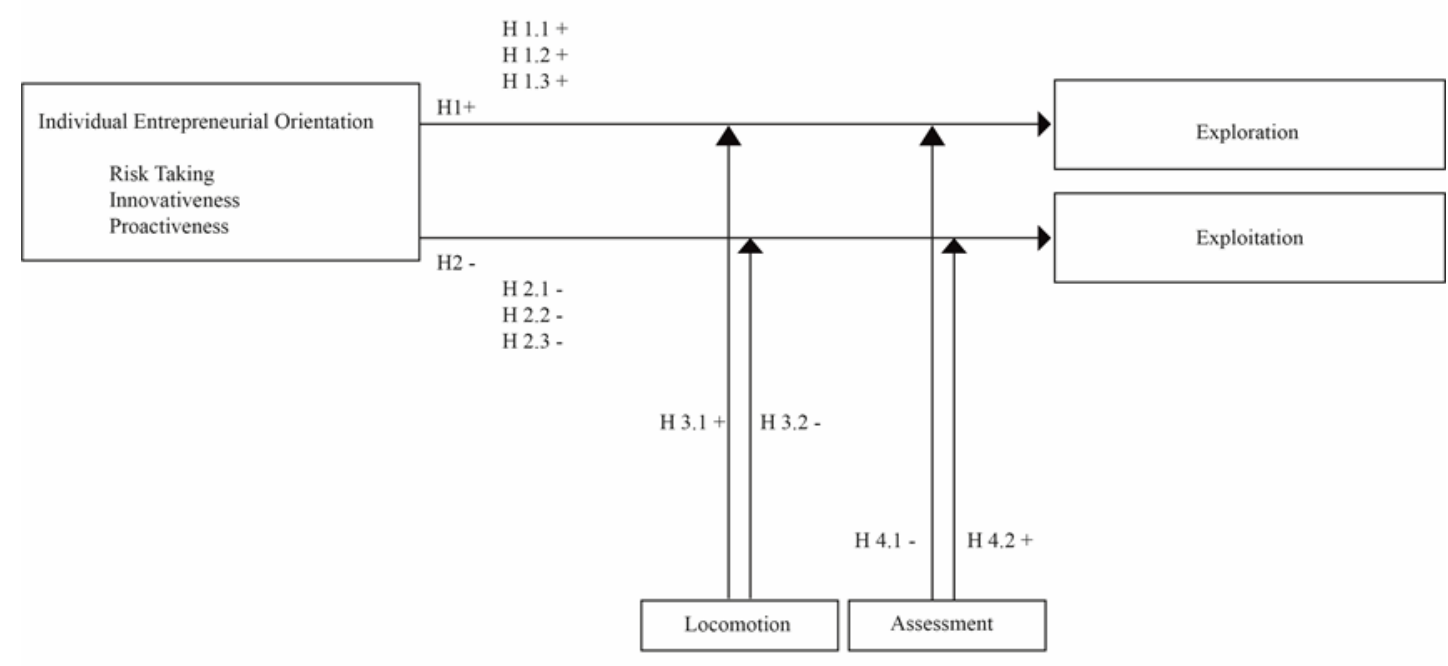

Moderator

Fig. 1 Research model

The scales used for the survey are based on reliable and valid constructs taken from existing literature:

Individual entrepreneurial orientation: The IEO scale used is developed by Bolton and Lane (2012) and shows three different subdimensions (risk-taking, innovativeness and proactiveness). A factor analysis led to the removal of unsatisfactory items resulting in a Cronbach's alpha value of .626. Similar results occurred in existing literature (Bolton and Lane, 2012; Bolton, 2012).

Individual-level exploration and exploitation: As a dependent variable, the study considers individual-level exploration and exploitation by Mom, van den Bosch \& Volberda (2009). The factor analysis resulted in a Cronbach's Alpha of .841 for exploration and .724 for exploitation. One item of the exploitation scale was eliminated because of a high cross-loading.

Locomotion and assessment: For the moderator variables, self-regulating modes of locomotion and assessment, the scale used is a German version of the original one from Kruglanski et al. (2000), translated by Sellin et al. (2003). Because of insufficient factor loadings three items were removed. The final Cronbach's Alpha were .740 for Locomotion and .756 for Assessment.

Table 1 shows the means, standard deviations and correlations of the applied variables. 
Table 1 Mean, standard deviation and correlations

\begin{tabular}{|c|c|c|c|c|c|c|c|c|c|c|c|c|}
\hline \multicolumn{2}{|c|}{ Mean } & \multirow{2}{*}{$\begin{array}{l}\text { Std. Dev. } \\
.50\end{array}$} & \multirow{2}{*}{$\begin{array}{l}\text { Gender } \\
1\end{array}$} & \multirow[t]{2}{*}{ Education } & \multirow[t]{2}{*}{ Risk } & \multirow[t]{2}{*}{$\begin{array}{l}\text { Innova- } \\
\text { tion }\end{array}$} & \multirow[t]{2}{*}{$\begin{array}{l}\text { Proactive- } \\
\text { ness }\end{array}$} & \multirow[t]{2}{*}{ IEO } & \multirow[t]{2}{*}{$\begin{array}{l}\text { Locomo- } \\
\text { tion }\end{array}$} & \multirow[t]{2}{*}{$\begin{array}{l}\text { Assess- } \\
\text { ment }\end{array}$} & \multirow[t]{2}{*}{$\begin{array}{l}\text { Explora- } \\
\text { tion }\end{array}$} & \multirow[t]{2}{*}{$\begin{array}{l}\text { Exploita- } \\
\text { tion }\end{array}$} \\
\hline Gender & 1.52 & & & & & & & & & & & \\
\hline Education & 3.07 & 1.38 & $-.184^{* *}$ & 1 & & & & & & & & \\
\hline Risk & 3.45 & .57 & $-0,105$ & $.163^{* *}$ & 1 & & & & & & & \\
\hline Innovation & 3.50 & .61 & $-0,043$ & $.122^{*}$ & $.373^{* *}$ & 1 & & & & & & \\
\hline Proactiveness & 4.12 & .50 & $-0,043$ & $-0,018$ & 0,072 & 0,021 & 1 & & & & & \\
\hline IEO & 3.69 & .37 & $-0,096$ & $.141^{*}$ & $.740^{* *}$ & $.743^{* *}$ & $.495^{* *}$ & 1 & & & & \\
\hline Locomotion & 4.40 & .52 & $-0,002$ & 0,067 & $.465^{* *}$ & $.309^{* *}$ & $.229^{* *}$ & $.505^{* *}$ & 1 & & & \\
\hline Assessment & 3.33 & .69 & $-0,113$ & 0,093 & 0,067 & $.152^{*}$ & 0,046 & $.137^{*}$ & $.202^{* *}$ & 1 & & \\
\hline Exploration & 3.78 & .95 & $-.202^{* *}$ & $.241^{* *}$ & $.445^{* *}$ & $.336^{* *}$ & $.202^{* *}$ & $.498^{* *}$ & $.468^{* *}$ & $.134^{*}$ & 1 & \\
\hline Exploitation & 3.96 & .67 & $-0,039$ & $-.181^{* *}$ & $-0,061$ & $-0,095$ & $.134^{*}$ & $-0,023$ & 0,091 & $.163^{* *}$ & $-0,068$ & 1 \\
\hline
\end{tabular}

Notes. $\mathrm{n}=266 ; * \mathrm{p}<0.05 ; * * \mathrm{p}<0.01$ (two-tailed). 


\section{Results}

To test the hypotheses, we used correlation and regression analysis. Regarding hypotheses H1, H1.1, H1.2 H1.3, Table 2 shows the results of the regression analysis of IEO and its subdimensions influencing explorational activities. The results demonstrate significant relationships among the variables. Therefore, the whole block of $\mathrm{H} 1$ was accepted. Considering the block of hypotheses H2 (Table 3) only a positive significance for proactiveness is found. Therefore, there seems to be no relationship among IEO and exploitation. So, the hypotheses $\mathrm{H} 2, \mathrm{H} 2.1, \mathrm{H} 2.2$ and $\mathrm{H} 2.3$ are rejected.

Table 2 Summary of regression analyses of exploration

\begin{tabular}{llcc}
\hline & Standardized Beta Factor & $\mathrm{R}^{2}$ & Corrected $\mathrm{R}^{2}$ \\
\hline H1 IEO & $.498^{* * *}$ & .248 & .245 \\
\hline H1.1 Risk & $.385^{* * *}$ & & .251 \\
H1.2 Innovation & $.199^{* *}$ & .261 & \\
H1.3 Proactiveness & $.172^{* *}$ & & \\
\hline
\end{tabular}

Dependent variable: Exploration

$\mathrm{n}=266$,

$* \mathrm{p}<.05 ; * * \mathrm{p}<.01 ; * * * \mathrm{p}<0.001$

Table 3 Summary of regression analyses of exploitation

\begin{tabular}{llcc}
\hline & Standardized Beta Factor & $\mathrm{R}^{2}$ & Corrected $\mathrm{R}^{2}$ \\
\hline $\mathrm{H} 2$ IEO & -.023 & .001 & -.003 \\
\hline H2.1 Risk & -.040 & & \\
H2.2 Innovation & -.083 & .029 & .018 \\
H2.3 Proactiveness & $.139 *$ & & \\
\hline
\end{tabular}

Dependent variable: Exploitation

$\mathrm{n}=266$;

$* \mathrm{p}<.05 ; * * \mathrm{p}<.01 ; * * * \mathrm{p}<0.001$

The results of the moderating variable locomotion (Table 4) show that it fosters the relationship of IEO and exploration and does not have a significant effect on the IEO and exploitation relationship. Concluding, H3.1 is confirmed while H3.2 is rejected. Turning to hypotheses H4.1 and H4.2, the effect of 
assessment on the direct relationships, the results (Table 5) indicate that assessment harms the relationship of IEO and exploration and supports the relationship of IEO and exploitation. So, both hypotheses are accepted.

Table 4 Summary of regression analyses of the locomotion effect

\begin{tabular}{llll}
\hline & Standardized Beta Factor & $\mathrm{R}^{2}$ & Corrected $\mathrm{R}^{2}$ \\
\hline H3.1 IEO and Locomotion & $.561^{* * *}$ & .314 & .312 \\
& & & \\
\hline
\end{tabular}

Dependent variable: Exploration

\begin{tabular}{llll}
\hline H3.2 IEO and Locomotion & .050 & .002 & -.001
\end{tabular}

Dependent variable: Exploitation

$\mathrm{n}=266$;

$* \mathrm{p}<.05 ; * * \mathrm{p}<.01 ; * * * \mathrm{p}<0.001$

Table 5 Summary of regression analyses of the assessment effect

\begin{tabular}{llll}
\hline & Standardized Beta Factor & $\mathrm{R}^{2}$ & Corrected $\mathrm{R}^{2}$ \\
\hline H4.1 IEO and Assessment & $.322^{* * *}$ & .104 & .101
\end{tabular}

Dependent variable: Exploration

\begin{tabular}{llll}
\hline H4.2 IEO and Assessment & $.138^{*}$ & .019 & .015
\end{tabular}

Dependent variable: Exploitation

$\mathrm{n}=266$;

$* \mathrm{p}<.05 ; * * \mathrm{p}<.01 ; * * * \mathrm{p}<0.001$

Table 6 Hypotheses results summary

\section{Hypothesis}


H1.1 The higher IEO Risk characteristics are, the higher the value of exploration.

H1.2 The higher IEO Innovation characteristics are, the higher the value of exploration.

H1.3 The higher IEO Proactiveness characteristics are, the higher the value of exploration.

$\mathrm{H} 2$ The higher the IEO characteristics of an employee, the lower the value of exploitation.

H2.1 The higher IEO Risk characteristics are, the lower the value of exploitation.

H2.2 The higher IEO Innovation characteristics are, the lower the value of exploitation. NO

H2.3 The higher IEO Proactiveness characteristics are, the lower the value of exploitation. NO

H3.1 Locomotion positively influences the relationship of IEO and exploration activities. YES

H3.2 Locomotion negatively influences the relationship of IEO and exploitation.

H4.1 Assessment negatively influences the relationship of IEO and exploration activities.

Table 6 and Figure 2 give an overview on the hypotheses and the general results of the empirical tests.

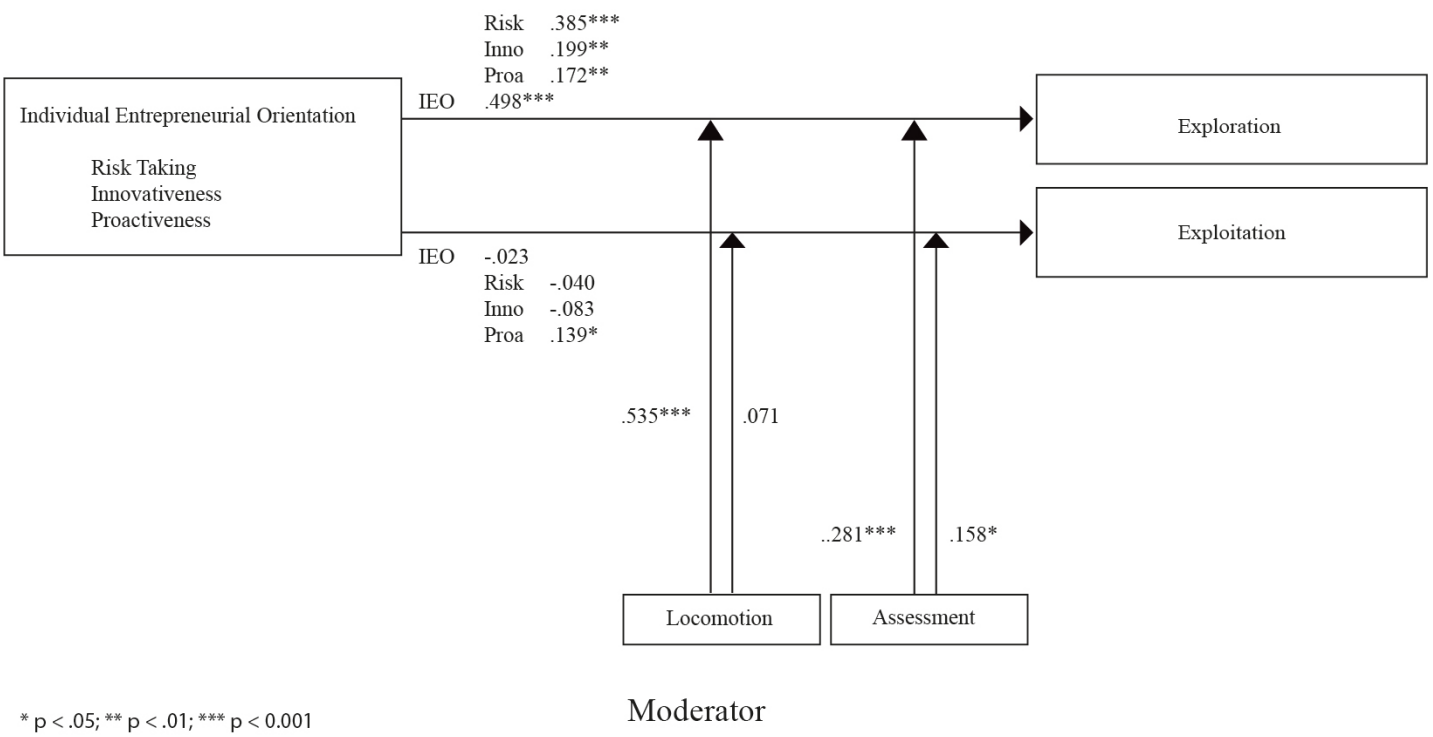

Fig. 2 Results shown in the research model 


\section{Discussion}

EO is often described as vital to organizational performance. The positive revitalizing effect of EO is regularly reported in the literature (Rauch et al., 2009). But, there remains a theoretical and conceptual leap from organizational EO to entrepreneurial behaviors and intrapreneurial outcomes elsewhere in the organization and especially among individuals; and it is ultimately upon the behaviors of individuals that organizational activity and corporate entrepreneurship depend. This study investigated the relationship of IEO and exploration and exploitation as a consequence. Explorative activities are a necessary part of intrapreneurship. Literature suggests that the intrapreneurial process starts with a new logic, which means the creation of something new (Heinze \& Weber, 2016; Sarasvathy, 2001; Eckhardt \& Shane, 2003). Thus, creation of a new product, service or process can be enhanced through participating in explorative activities, and those individuals engaging on more explorative work are more likely to detect larger numbers of opportunities, and especially novel ones. We reveal the primacy of IEO to germinating exploration.

Entrepreneurially oriented employees are highly effective explorers according to our results. The results showed that IEO is strongly connected to explorative activities. Organizations that are willing to renew themselves and create innovations should therefore find or develop employees with a high amount of IEO. These employees are innovation drivers that create and find new opportunities. Kearny et al. (2008) has established a first model of public sector CE. The model consists of internal and external factors. In comparison to the research conducted in this study, only the internal factors are considered. The authors named structure, decision-making, rewards, culture, risk-taking and proactivity as factors to shape CE activities in public organizations. Our study highlights and sheds light on the beginning of the intrapreneurial process at the employee level and shows that both risk-taking and proactivity are necessary factors that lead to explorative activities. However, their model does not pay attention to the factor of innovation at first. They describe innovation as a result of the factors of proactiveness and risk. Russell (1999) describes internal innovation as something that is started by individuals or groups and can be influenced by the organization and the environment. Mulgan and Albury (2003) suggested several factors that described public sector organizations as a challenging environment for innovation. They draw attention to a culture of risk aversion and the lack of coping with risk and change management. This is a relevant point as our study revealed the highest beta factors for the relationship of risk and exploration, which suggests that the higher the ability of a public sector employee for risk-taking, the more time they spend on explorative activities within the organization. A meta-analysis on EO and performance shows a positive but less significant relationship for the risk dimension (Rauch et al., 2004). Bureaucratic organizations are generally seen as less risky than other organizations. They are more closely associated to exploitative tasks. Changes in the working process often reflect legislation changes and therefore require a longer time duration. This could lead employees with a high level of individual risk to be more strongly associated to explorative activities. However, the literature suggests that there 
are major differences in the individual and the organizational risk dimension (Mustafa et al., 2018). The risk dimension in IEO should be further researched to answer the question of how organizational and individual risk differ.

The intrapreneurial process is divided into two parts. Part one is the recognition of opportunities and part two is the exploitation of opportunities. Often employers are afraid that employees concentrating on the identification of new opportunities are less effective in exploiting opportunities. This hypothesis could not be supported in this study. Although the authors could not show the opposite effect, the hypothesis is still overruled. Therefore, there still exists the possibility of a perfect intrapreneur that can act on both exploration and exploitation. This result is further supported through the research of Heinze \& Weber (2016), in which they demonstrated that in some organizations the person that discovers an opportunity is the same person who exploits this opportunity.

Minimal literature deals with the relationship of entrepreneurship and self-regulation. However, Amato et al. (2017) found that existing research and literature imply a strong relationship between entrepreneurship and self-regulation. They evidenced the first set of results of this relationship by indicating that people high on locomotion are successful in scanning for new opportunities. A high level of assessment indicates that employees are strong in evaluating these new opportunities. Since the literature suggests that it is possible to be a locomotor and an assessor concurrently, this describes a successful intrapreneur, a person being able to identify and evaluate an opportunity. Combining existing research with the results of this study a clear image of a potentially successful intrapreneur can be drawn.

Our moderator analysis suggests that a person with high IEO and high locomotion works on explorative tasks and is therefore a perfect fit for an organization seeking new opportunities. As locomotion is related to intrinsic motivation, this is a further indication that employees with a high level of locomotion are vital for intrapreneurship (Kruglanski \& Higgins, 2006; Pierro et al. 2006). Within existing literature, assessment is positively related to the ability of evaluating opportunities, which is a crucial second part of intrapreneurship. Assessing opportunities actively helps intrapreneurs to identify unrealistic opportunities and resolve them. Therefore, the assessment process decreases the personal risk an intrapreneur must take. This investigation showed that the moderator assessment plays an important role. However, between IEO and exploitation there is no significant relationship. This suggests that a pure IEO does not influence an employee's exploitative activities. However, the results of the moderating effect demonstrate that individuals with an assessment attitude do engage in exploitational activities.

Literature further suggests that it is possible to be strong in locomotion as well as assessment (Amato et al., 2017), which provides the possibility of an archetype of an intrapreneur who is strong in scanning for new opportunities and evaluating them. Since literature also supports the possibility of an individual being able to successfully engage in exploration and exploitation activities simultaneously (Mom et al., 2009) this further supports the possibility of a perfect Intrapreneur. To conclude, this study 
shows that locomotion and assessment do have a strong connection to intrapreneurship. The results highlighted that there is the theoretical possibility of a perfect Intrapreneur. This intrapreneur is shaped through a high level of IEO, in combination with a strong balanced level of locomotion and assessment and exploration and exploitation.

\section{Conclusion}

Municipalities and cities must show innovative approaches. Either they must develop strategies for individual challenges, or they need to integrate solutions from private companies. In both cases, intrapreneurial action is required. While a long list of private companies are providing innovative solutions for cities and municipalities, the stereotype of an inefficient administration remains predominant. Decision cycles in municipalities and cities are long and often follow a steep hierarchy. Based on the democratic system political key Decision-makers (e.g. mayors) are often changed, resulting in an increased importance of individual employees. They must see an opportunity and start to pursue it either internally or work with external companies.

For municipalities and cities, innovative behavior appears increasingly crucial to their sustainability. For example, an increasing number of cities are using social media to communicate with citizens. Others use solutions that arouse with the "Internet of Things" to measure water levels and create novel ways of risk management. Therefore, these organizations should hire employees with the potential to engage in explorative activities to find further solutions. Employees with a high level of IEO fulfil this description. Decision-makers in municipalities and cities can use the ten items of IEO to explore their potential employees on their level of IEO. On this foundation, an organization can create a highly effective team for undertaking intrapreneurial activities.

Decision-makers should be aware of the innovation potential of existing employees. Based on the level of IEO, heterogeneous teams can be created for explorative tasks. Furthermore, employees with a high level of IEO that are mostly working on exploitative activities could be transferred to more explorative activities to prevent them from looking for a new job because of dissatisfaction. Employees with a high level of IEO are more likely to be interested in explorative than exploitative jobs. To effectively engage in intrapreneurial activities, the responsible ones can create teams for explorative tasks. To increase the level of IEO and the general EO of the team, educational programmes could be a potential solution. With trainings and workshops employees already working on explorative tasks could increase their awareness for opportunities. Municipalities and cities that are interested in innovative behavior should consider hiring employees with a high level of IEO and create teams for intrapreneurial activities.

The moderator analysis further suggests that decision-makers should check on the regulatory mode of their employees. People with a locomotion mind-set are more likely to engage in explorational 
activities than the ones with an assessment mind-set. A locomotion mind-set is shaped by an ongoing transition. Locomotion describes a state of moving. It can be used to describe a design thinking innovation process. For this process a lot of ideas are collected and evaluated throughout the whole process (Beckman \& Barry, 2007). On the other hand, a high level of assessment would try to find one idea and assess it deeply.

In recent years, the private sector created several solutions for municipalities and cities. This study suggests, that especially sales teams should wisely consider their first contact within a city or municipality. A contact person with a low level of IEO is less interested in explorative tasks and seems to be the wrong choice for a first contact with an innovative product or service. Employees with a high level of IEO could be more fostering and help private companies to sell their solution to cities and municipalities. However, the question results of how to identify these employees. We suggest a solution in the following section.

\section{Limitations, problems and future research}

As every research, also ours holds some limitations. First, this research is designed as a cross-sectional analysis. To overcome this limitation, a second study should be conducted to identify the issues time has on the outcome. Because the entrepreneurial mind-set of an employee is nothing that changes within months or even years, the results are expected to be similar. Second, the geographical bias builds another limitation. For this study, only German-speaking organizations were involved. Germanic countries are very similar from a cultural point of view because of their close geographical separation and the shared language. Although several studies showed that the cultural effect on EO is only weak, a cross-cultural study with respondents on different continents could strengthen the establishment of IEO as a scale and support this study. Furthermore, this study only deals with employees of municipalities and cities. To overcome this limitation, a further study should investigate the relationship of IEO and exploration/exploitation on a corporate level. Third, this study was conducted under the limitation of self-assessment. Because of this, the participants had to rate themselves. This limitation could be overruled through a third-party assessment. The discussion about risk showed potential interpretations for the strong result of the risk dimension. There are different factors that could have caused this outcome. To further investigate the difference among personal and organizational risk, further studies with the use of IEO scales in different populations are necessary. However, we also demonstrated that the result is possibly based on the population used in this study. Further investigation could help to answer this question.

A unique characteristic of municipalities and cities are that their key decision-makers are legitimized through elections. Therefore, the leaders in these organizations are not always educated to lead organizations of these sizes. Future research should deal with the question of what effect the leadership qualities of mayors might have on their authorities. We also suggested that private companies have to 
consider their contact partner in municipalities and cities wisely. To sell an innovative product or service to a city, it is necessary to address the best potential partner that could help to convince the rest of the decision-makers. This person seems to be a person with a high level of IEO. However, it is not easy to identify the level of IEO for an employee of another organization. Therefore, we suggest further research exploring the intersection of IEO and personal public profiles on social media such as LinkedIn, Xing, Facebook etc. Research could help to identify employees with a high level of IEO based on public profiles.

Furthermore, in recent years the context of smart city developments flourished. Cities and municipalities seem to be a fruitful area for entrepreneurship and intrapreneurship research. Therefore, we suggest to concentrate on smart city developments and their relationship with entrepreneurship and intrapreneurship in future research. Cities and municipalities are important employers that are strongly faced global changes like digitalization, climate change, demographic changes and so on. In recent years, they were typically administratively focused organizations with steep hierarchies. Future research could concentrate on the relationship of adopting new technologies in cities and municipalities and the overall EO within the organization. Cities and municipalities are an interesting research object in the area of business model innovation. In recent years they realized that they do own a lot of data. Individual cities are already starting to provide this data to private organizations. The case of a city or municipality as data provider is novel and could result in completely new money streams. 


\section{Appendix}

Table 7: Constructs, subdimensions, items and sources of the online survey

\begin{tabular}{|c|c|c|c|}
\hline Construct & Subdimensions & Items & Source \\
\hline \multirow{15}{*}{$\begin{array}{l}\text { Individual En- } \\
\text { trepreneurial } \\
\text { Orientation }\end{array}$} & \multirow[t]{4}{*}{ Risk-taking } & I like to take bold action by venturing into the unknown & Bolton \& \\
\hline & & I am willing to invest a lot of time and/or money on some- & \multirow[t]{14}{*}{ Lane, 2012} \\
\hline & & thing that might yield a high return & \\
\hline & & I tend to act "boldly" in situations where risk is involved & \\
\hline & \multirow[t]{8}{*}{ Innovation } & In general, I prefer a strong emphasis in projects on & \\
\hline & & unique, one-of-a-kind approaches rather than revisiting & \\
\hline & & tried and true approaches used before & \\
\hline & & I prefer to try my own unique way when learning new & \\
\hline & & things rather than doing it like everyone else does & \\
\hline & & I favour experimentation and original approaches to prob- & \\
\hline & & lem solving rather than using methods others generally & \\
\hline & & use for solving their problems & \\
\hline & \multirow[t]{3}{*}{ Proactiveness } & I usually act in anticipation of future problems, needs or & \\
\hline & & changes & \\
\hline & & I tend to plan ahead on projects & \\
\hline \multirow{19}{*}{$\begin{array}{l}\text { Self-Regula- } \\
\text { tion }\end{array}$} & \multirow[t]{14}{*}{ Locomotion } & I don't mind doing things even if they involve extra effort. & \multirow{14}{*}{$\begin{array}{l}\text { Sellin et al., } \\
2003 \text {; } \\
\text { Kruglanski } \\
\text { et al. } 2000\end{array}$} \\
\hline & & I am a "workaholic. & \\
\hline & & I feel excited just before I am about to reach a goal. & \\
\hline & & I enjoy actively doing things, more than just watching and & \\
\hline & & observing. & \\
\hline & & I am a "doer." & \\
\hline & & When I decide to do something, I can't wait to get started. & \\
\hline & & By the time I accomplish a task, I already have the next & \\
\hline & & one in mind. & \\
\hline & & Most of the time my thoughts are occupied with the task & \\
\hline & & I wish to accomplish. & \\
\hline & & When I get started on something, I usually persevere until & \\
\hline & & I it. & \\
\hline & & I am a "go-getter." & \\
\hline & \multirow[t]{5}{*}{ Assessment } & I spend a great deal of time taking inventory of my posi- & \\
\hline & & tive and negative characteristics. & \\
\hline & & I like evaluating other people's plans. & \\
\hline & & I often compare myself with other people. & \\
\hline & & I often critique work done by myself or others & \\
\hline
\end{tabular}


I often feel that I am being evaluated by others

I am a critical person

I am very self-critical and self-conscious about what I am saying

I often think that other people's choices and decisions are wrong.

When I meet a new person I usually evaluate how well he or she is doing on various dimensions (e.g., looks, achievements, social status, clothes).

Table 7 (continued)

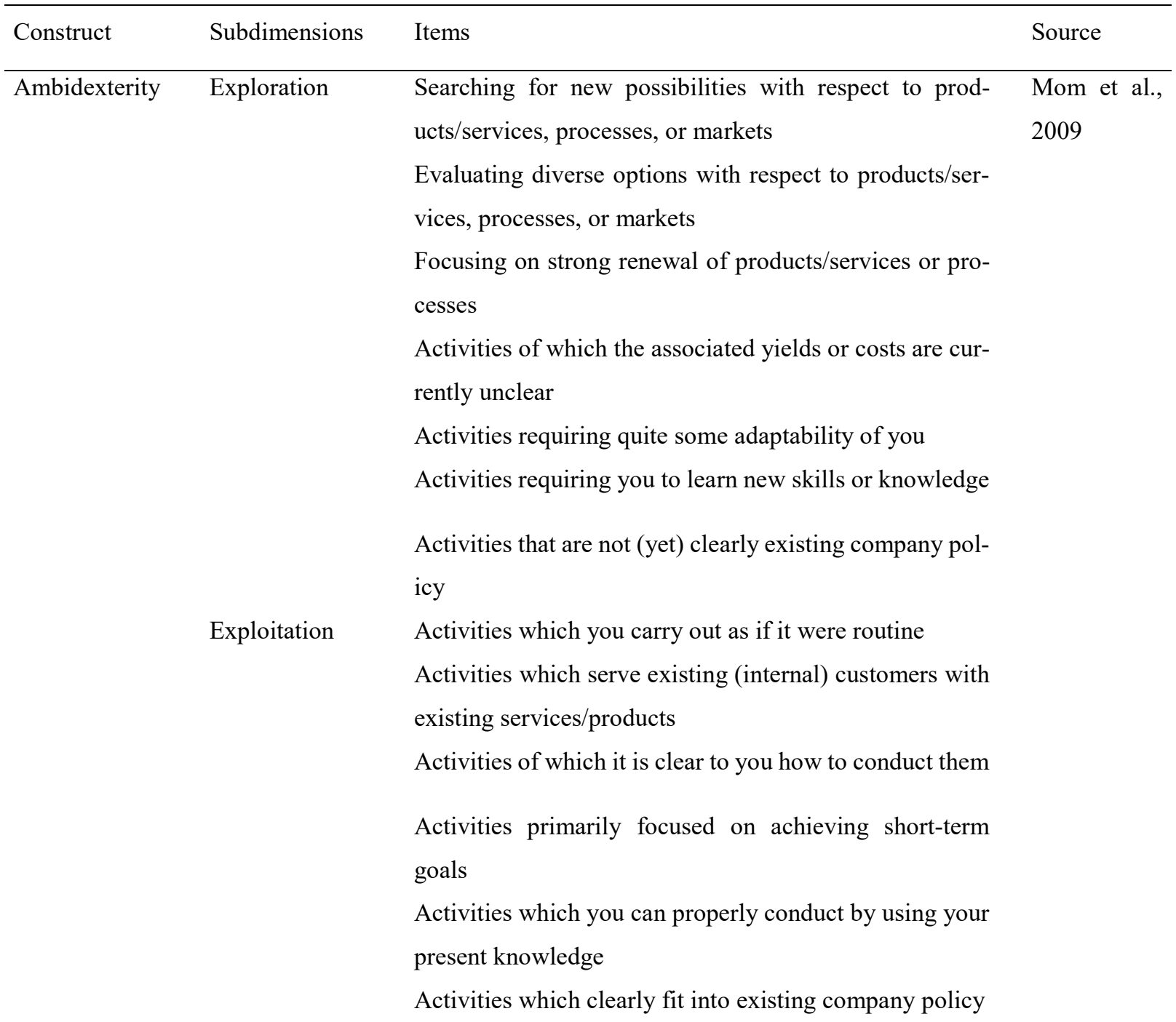




\section{List of references}

Amato, C., Baron, R.A., Barbieri, B., Bélanger, J.J. \& Pierro, A. (2017). Regulatory Modes and Entrepreneurship: The Mediational Role of Alertness in Small Business Success. Journal of Small Business Management, 55(S1), 27-42.

Anderson, B.S., Kreiser, P.M., Kuratko, D.F., Hornsby, J.S., \& Eshima, Y. (2015). Reconceptualizing entrepreneurial orientation. Strategic Management Journal, 36(10), 1579-1596.

Antoncic, B. \& Hisrich, R. (2001). Intrapreneurship: construct refinement and cross-cultural validation. Journal of Business Venturing, 16(5), 495-527.

Atuahene-Gima, K. (2005). Resolving the capability-rigidity paradox in new product innovation. Journal of Marketing, 69, 61-83.

Avnet, T., \& Higgins, E. T. (2003). Locomotion, assessment, and regulatory fit: Value transfer from "how" to "what". Journal of Experimental Social Psychology, 39(5), 525-530.

Battilana, J. (2006). Agency and institutions: The enabling role of individuals' social position. Organization, 13(5), 653-676.

Beckmann, S.L. \& Barry, M. (2007). Innovation as a Learning Process: Embedding Design Thinking. California Management Review, 50(1), 25-56.

Bolton, D.L. (2012). Individual Entrepreneurial Orientation: Further investigation of a measurement instrument. Academy of Entrepreneurship Journal, 8(1), 91-97.

Bolton, D.L. \& Lane, M.D. (2012). Individual entrepreneurial orientation: development of a measurement instrument. Education + Training, 54(2/3), 219-233.

Briscoe, F. \& Safford, S. (2008). The Nixon-in-China effect: Activism, imitation, and the institutionalization of contentious practices. Administrative Science Quarterly, 53(3), 460-491.

Burgelman, R.A. (1983). A process model of internal corporate venturing in the diversified major firm. Administrative Science Quarterly, 28, 223-244.

Burgelman, R.A. (1985). Managing the new venture division: Research findings and implications for strategic management. Strategic Management Journal, 6(1), 39-54.

Cantillon, R. (1734). Essai sur la nature du commerce en general [Essay on the nature of general commerce]. (Henry Higgs, Trans.). London: Macmillan,

Carrier, C. (1996). Intrapreneurship in Small Businesses: An Exploratory Study. Entrepreneurship Theory and Practice, 21(1), 5-20.

Covin, J. G., Green, K. M. \& Slevin, D. P. (2006). Strategic process effects on the entrepreneurial orientation-sales growth rate relationship. Entrepreneurship: Theory \& Practice, 30(1), 57-81. 
Covin, J.G., \& Miller, D. (2014). International entrepreneurial orientation: Conceptual considerations, research themes, measurement issues, and future research directions. Entrepreneurship Theory and Practice, 38(1), 11-44.

Covin, J.G., \& Slevin, D.P. (1989). Strategic management of small firms in hostile and benign environments. Strategic Management Journal, 10, 75-87.

Covin, J.G., \& Slevin, D.P. (1991). A conceptual model of entrepreneurship as firm behavior. Entrepreneurship Theory and Practice, 16(1), 7-25.

Covin, J.G., \& Wales, W.J. (2019). Crafting high-impact entrepreneurial orientation research: Some suggested guidelines. Entrepreneurship Theory and Practice, 43(1), 3-18.

Croonen, E. P., Brand, M. J. \& Huizingh, E. K. (2016). To be entrepreneurial, or not to be entrepreneurial? Explaining differences in franchisee entrepreneurial behavior within a franchise system. International Entrepreneurship and Management Journal, 12(2), 531-553.

Day, D.L. (1994). Raising radicals: different processes for championing innovative corporate ventures. Organization Science, 5(2), 148-72.

Eckhardt, J.T. \& Shane, S.A. (2003). Opportunities and entrepreneurship. Journal of Management, 29(3), 333-349.

Eggers, F., Niemand, T., Kraus, S., \& Breier, M. (2018). Developing a scale for entrepreneurial marketing: Revealing its inner frame and prediction of performance. Journal of Business Research. DOI: https://doi.org/10.1016/j.jbusres.2018.11.051.

Furtner, M. \& Sachse, P. (2017). Selbstregulation und Führungsverhalten. Beziehungen zwischen Formen der Selbstregulation, transformationaler, transaktionaler und Laissez-faire-Führung. Wirtschaftspsychologie, 1(2017), 30-40.

Guth, W.D., \& Ginsberg, A. (1990). Corporate entrepreneurship. Strategic Management Journal, 11, 515.

Hage, J. (1980). Theories of organizations. New York: Wiley.

Hambrick, D.C., \& Mason, P.A. (1984). Upper echelons: The organization as a reflection of its top managers. Academy of Management Review, 9(2), 193-206.

Haveman, H.A. \& Rao, H. (1997). Structuring a theory of moral sentiments: Institutional and organizational coevolution in the early thrift industry. American Journal of Sociology, 102(6), 1606-1651.

Heinonen, J. and Toivonen, J. (2008). Corporate entrepreneurs or silent followers? Leadership \& Organization Development Journal, 29(7), 583-599. 
Heinze, K.L. \& Weber, K. (2016). Toward Organizational Pluralism: Institutional Intrapreneurship in Integrative Medicine. Organization Science, 27(1), 157-172.

Higgins, E. T., Kruglanski, A. W. \& Pierro A. (2003). Regulatory mode: Locomotion and assessment as distinct orientations. In: M. P. Zanna, (Ed.), Advances in experimental social psychology. New York: Academic Press.

Hisrich, R.D. \& Peters, M.P. (1984). Internal venturing in large corporations. In: J.A. Hornaday, et al., eds., Frontiers of Entrepreneurship Research. Wellesley, MA: Babson College.

Howard-Grenville, J.A. (2007). Developing issue-selling effectiveness over time: Issue selling as resourcing. Organization Science, 18(4), 560-577.

Hughes, M., \& Mustafa, M. (2017). Antecedents of corporate entrepreneurship in SMEs: Evidence from an emerging economy. Journal of Small Business Management, 55(S1), 115-140.

Hughes, M., \& Morgan, R. E. (2007). Deconstructing the relationship between entrepreneurial orientation and business performance at the embryonic stage of firm growth. Industrial Marketing Management, 36(5), 651-661.

Hughes, M., Rigtering, J.C.P., Covin, J.G., Bouncken, R. \& Kraus, S. (2018). Innovative Behaviour, Trust and Perceived Workplace Performance. British Journal of Management, Vol. 29(4), 750-768.

Kanter, R.M. (1984). The Change Masters. New York, NY: Touchstone, Simon \& Schuster.

Kanter, R.M. \& Richardson, L. (1991). Engines of progress: Designing and running entrepreneurial vehicles in established companies-The Enter-prize program at Ohio Bell, 1985-1990. Journal of Business Venturing, 6(3), 209-229.

Kearney, C., Hisrich, R., \& Roche, F. (2008). A conceptual model of public sector corporate entrepreneurship. International Entrepreneurship and Management Journal, 4, 295-313.

Knight, G.A. (1997). Cross-cultural reliability and validity of a scale to measure firm entrepreneurial orientation. Journal of Business Venturing, 12, 213-225.

Kraatz, M.S. \& Block, E. (2008). Organizational implications of institutional pluralism. In: Greenwood, R., Oliver, C., Sahlin, K. \& Suddaby, R. eds. The SAGE Handbook of Organizational Institutionalism. Sage Publications, Thousand Oaks, CA, 243-261.

Kraus, S., Kallmuenzer, A., Stieger, D., Peters, M., \& Calabrò, A. (2018). Entrepreneurial paths to family firm performance. Journal of Business Research, 88, 382-387.

Kraus, S., Niemand, T., Besler, M., Stieg, P., \& Martinez-Ciment, C. (2018). The influence of leadership styles on the internationalisation of 'born-global'firms and traditionally globalexpanding firms'. European Journal of International Management, 12(5/6), 554-575. 
Kruglanksi, A. W. \& Higgins, E. T. (2006). Regulatory mode and the joys of doing: effects of 'locomotion' and 'assessment' on intrinsic and extrinsic task-motivation. European Journal of Personality, $20,355-375$.

Kruglanski, A. W., Thompson, E. P., Higgins, E. T., Atash, M. N., Pierro, A., Shah, J. Y. \& Spiegel, S. (2000). To "do the right thing" or to "just do it": Locomotion and assessment as distinct selfregulatory imperatives. Journal of Personality and Social Psychology, 79, 793-815.

Kuhl, J. (1983). Motivation, Konflikt und Handlungskontrolle. Berlin: Springer.

Kuhl, J. (1985). Volitional mediation of cognition-behavior consistency: self-regulatory processes and action versus state orientation. In: $J$. Kuhl \& J. Beckman (Eds.), Action control: from cognition to behaviour (pp. 101-128). Berlin: Springer.

Kuratko, D.F., Morris, M.H. \& Covin, J.G. (2011). Corporate innovation and entrepreneurship: entrepreneurial development within organizations. $3^{\text {rd }}$ Ed., Mason, Ohio, South-Western Cengage Learning.

Kyriakopoulos, K., Hughes, M., \& Hughes, P. (2016). The role of marketing resources in radical innovation activity: Antecedents and payoffs. Journal of Product Innovation Management, 33(4), 398417.

Lumpkin, G.T. \& Dess, G.G. (1996). Clarifying the entrepreneurial orientation construct and linking it to performance. Academy of Management Review, 21(1), 135-172.

Lumpkin, G.T. \& Dess, G.G. (2001). Linking two dimensions of entrepreneurial orientation to firm performance: The moderating role of environment and industry life cycle. Journal of Business Venturing, 16, 429-451.

MacMillan, I.C., Block, Z. \& Narasimha, P.N.S. (1984). Obstacles and experience in corporate ventures. In: J.A. Hornaday et al., eds., Frontiers of Entrepreneurship Research. Wellesley, MA: Babson College.

McKinney, G. \& McKinney, M. (1989). Forget the corporate umbrella-Entrepreneurs shine in the rain. Sloan Management Review, 30(4), 77-82.

Meyerson, D.E. \& Scully, M.A. (1995). Tempered radicalism and the politics of ambivalence and change. Organization Science, 6(5), 585-600.

Miller, D. \& Friesen, P. H. (1978). Archetypes of strategy formulation. Management Science, 24 (9), 921-933.

Mom, T. J. M., van den Bosch, F. A. J. \& Volberda, H W. (2009). Understanding Variation in Managers' Ambidexterity: Investigating Direct and Interaction Effects of Formal Structural and Personal Coordination Mechanisms. Organization Science, 20(4), 812-828. 
Mulgan, G., \& Albury, D. (2003). Innovation in the public sector. Strategy Unit, Cabinet Office, October 2003.

Mustafa, M., Gavin, F. \& Hughes, M. (2018). Contextual Determinants of Employee Entrepreneurial Behavior in Support of Corporate Entrepreneurship: A Systematic Review and Research Agenda. Journal of Enterprising Culture, 26(3), 285-326.

Mustafa, M., Martin, L. and Hughes, M. (2016). Psychological ownership, job satisfaction, and middle manager entrepreneurial behavior. Journal of Leadership \& Organizational Studies, 23(3), 272287.

Muzyka, D., Koning, A.D., Churchill, N. (1995). On transformation and adaptation: Building the entrepreneurial corporation. European Management Journal, 13(4), 346-362.

Pierro, A., Kruglanski, A. W. \& Higgins, E. T. (2006). Regulatory mode and the joys of doing: effects of 'locomotion' and 'assessment' on intrinsic and extrinsic task-motivation. European Journal of Personality, 20, 355-375.

Pinchot, G. (1985). Intrapreneuring: why you don't to leave the corporation to become an entrepreneur. New York: Harper \& Row.

Rauch, A., Wiklund, J., Lumpkin, G.T. \& Frese, M. (2009).Entrepreneurial Orientation and Business Performance: An Assessment of Past Research and Suggestions for Future. Entrepreneurship Theory and Practice, 33(3), 761-787.

Rauch, A. \& Hulsink, W. (2015). Putting Entrepreneurship Education Where the Intention to Act Lies: An Investigation Into the Impact of Entrepreneurship Education on Entrepreneurial Behavior. Academy of Management Learning \& Education, 14(2), 187-204.

Rule, E.G., \& Irwin, D.W. (1988). Fostering intrapreneurship: The new competitive edge. The Journal of Business Strategy, 9(3), 44-47.

Russell, R. D. (1999). Developing a process model of intrapreneurial systems: A cognition mapping approach. Entrepreneurship Theory and Practice, 23(3), 65-85.

Sarasvathy, S.D. (2001). Causation and effectuation: Toward a theoretical shift from economic inevitability to entrepreneurial contingency. Academy Management Review, 26(2), 243-263.

Schollhammer, H. (1981). The efficacy of internal corporate entrepreneurship strategies. In: K.H. Vesper, ed., Frontiers of Entrepreneurship Research. Wellesley, MA: Babson College.

Schollhammer, H. (1982). Internal corporate entrepreneurship. In: C.A. Kent, D.L. Sexton, and K.H. Vesper, eds., Encyclopedia of Entrepreneurship. Englewood Cliffs, NJ: Prentice-Hall.

Schumpeter, J. A. (1942). Capitalism, Socialism and Democracy. New York: Harper \& Brothers. 
Sellin, I., Schütz, A., Kruglanski, A. W. \& Higgins, E.T. (2003). Erfassung von Dimensionen der Selbstregulation. Der Locomotion-Assessment-Fragebogen (L-A-F). Forschungsbericht, TU Chemnitz.

Shane, S. (1994). Are champions different from non-champions? Journal of Business Venturing, 9(5), $397-421$.

Shane, S. \& Venkataraman, S. (2000). The promise of entrepreneurship as a field of research. Academy of Management Review, 25(1), 217-226.

Sine, W.D \& David, R.J. (2003). Environmental jolts, institutional change, and the creation of entrepreneurial opportunity in the US electric power industry. Research Policy, 32, 185-207.

Sok, K.M.; Sok, P. \& De Luca, L.M. (2016). The effect of 'can do' and 'reason to' motivations on service-sales ambidexterity. Industrial Marketing management, 55, 144-155.

Stevenson, H. H., \& Jarillo, J. C. (1990). A paradigm of entrepreneurship: Entrepreneurial management. Strategic Management Journal, 11, 17-27.

Stopford, J.M., \& Baden-Fuller, C.W.F. (1994). Creating corporate entrepreneurship. Strategic Management Journal, 15(7), 521-536.

Subramaniam, M. \& Youndt M. A. (2005). The influence of intellectual capital on the types of innovative capabilities. Academy of Management Journa , 48, 450-468.

Vesper, K.H. (1984). Three faces of corporate entrepreneurship: A Pilot Study. In:Livesay, H.C. (Hrsg.), Entrepreneurship and the growth of firms. Aldershot, 495-521.

Wales, W., Monsen, E. and McKelvie, A. (2011). The organizational pervasiveness of entrepreneurial orientation. Entrepreneurship Theory and Practice, 35(5), 895-923.

Weber, K., Heinze, K.L. \& DeSoucey M. (2008). Forage for thought: Mobilizing codes in the movement for grass-fed meat and dairy products. Administrative Science Quarterly, 53(3), 529-567.

Westphal, J.D., Zajac, E.J. (2001). Decoupling policy from practice: The case of stock repurchase programs. Administrative Science Quarterly, 46(2), 202-228.

Zahra, S.A. (1991). Predictors and financial outcomes of corporate entrepreneurship: An exploratory study. Journal of Business Venturing, 6, 259-285.

Zahra, S.A. (1993). A Conceptual Model of Entrepreneurship as Firm Behavior: A Critique and Extension. Entrepreneurship Theory and Practice, 17(4), 5-21.

Zampetakis, L. A. and Moustakis, V. (2007). Entrepreneurial behaviour in the Greek public sector. International Journal of Entrepreneurial Behavior \& Research, 13(1), 19-38. 
Public Sector Intrapreneurship

Zampetakis, L. A. and Moustakis, V. S. (2010). An exploratory research on the factors stimulating corporate entrepreneurship in the Greek public sector. International Journal of Manpower, 31(8), 871887.

Zietsma, C. \& Lawrence, T.B. (2010). Institutional work in the transformation of an organizational field: The interplay of boundary work and practice work. Administrative Science Quarterly 55(2), 189 221. 